\title{
Campaign for Clean and Healthy Living Behaviors on Anxiety Levels and Compliance with Clean and Healthy Living During the Covid-19 Pandemic
}

\author{
http://dx.doi.org/10.25008/ikiski.v6i2.562 \\ Suraya Mansur $^{1 *}$ Nurhayani Saragih $^{2}$, Isiaka Zubair Aliagan ${ }^{3}$ \\ ${ }^{1,2}$,Departmen of Communication Science, Universitas Mercu Buana \\ J1. Meruya Selatan No. 1 Jakarta 11610 - Indonesia \\ ${ }^{3}$ Kwara StateUniversity \\ Rd, 241103, Malete - Nigeria \\ "Corresponding author: suraya.suraya@mercubuana.ac.id
}

Submitted: August 12, 2021, Revised: September 20, 2021, Accepted: November 30, 2021 Accredited by Kemristekdikti No. 28/E/KPT/2019

\begin{abstract}
This research concerns the health communication campaign for Clean and Healthy Lifestyle (PHBS) during the Covid-19 pandemic among students of the graduate school of the University of Mercu Buana. This research found that the social learning theory proves effective in the campaign which leads to a change in society's behaviour. The theory used in this research is Albert Bandura's social learning theory. This research used positivistic paradigm. The method used in this research is a survey explanatory method and quantitative approach. The population is students of the graduate school at the University of Mercu Buana Jakarta. The sampling is conducted using purposive sampling techniques to 100 respondents, with a sampling error of $5 \%$. The technique of data analysis used in this research is simple regression analysis. The result shows that PHBS Campaign has no significant effect on Anxiety Level. PHBS Campaign has a significant effect on Compliance Level. Anxiety Level has no significant effect on Compliance Level. PHBS Campaign has no significant effect on Compliance Level through Anxiety Level.
\end{abstract}

Keywords: Social learning; campaign; clean and healthy lifestyle behaviour; anxiety; compliance

\section{Introduction}

Health communication is a part of human communication with the main focus on how individuals deal with health issues and how important to maintain their health. During the COVID-19 pandemic, health communication in the form of media campaign is used to educate health issues. Several things are discussed in the campaign, including Germas (the movement for healthy lifestyle) during the pandemic, a clean and healthy lifestyle, how to maintain good health, and how to deal with a disease. Health communication is also included as persuasive communication, because we can see it from its purpose of influencing and inviting the audience to change their attitudes and behavior in order to lead a healthy life. (Mohamad \& Azlan, 2020) (Sampurno et al., 2020); (Citrasiwi et al., 2017).

Behaviour is the main factor affecting the moral degree of society. There are so many health issues in Indonesia caused by those unable to have the Clean and Healthy Lifestyle (PHBS) or Clean and Healthy Lifestyle Behaviour. The PHBS covers 5 orders which are order in the household, order in the school, order in health institutions, order in the workplace, and order in public spaces. 
PHBS is the government program issued by the Ministry of Health in the Ministerial Decree of the Ministry of Health of the Republic of Indonesia No. $1193 / \mathrm{MENKES} / \mathrm{SK} / \mathrm{X} / 2004$. It is important to socialize PHBS because it concerns the lifestyle of society. PHBS needs to be socialized, disseminated, and enforced in places where many people gather.

The campaign for PHBS is a national program that continues to be improved to reach an ideal state of public health. As for the programs, PHBS has healthy lifestyle counselling, youth empowerment, healthy school, development, and lastly the development of media promoting the awareness of a healthy lifestyle. Some other programs intersect with the campaign program of PHBS and even support the implementation of the PHBS campaign.

PHBS is a social manipulation that aims to change as many people in the community as possible to be the agent of change that can raise the quality of daily behavior to live clean and healthy.

Since the outbreak of Corona Virus Disease (COVID-19) in Indonesia, many preventive efforts have been intensified. The focus of the preventive efforts is to break the chain of the COVID-19 spread. To that end, some effective ways are enforced such as social distancing, self-isolation, and the implementation of the clean and healthy lifestyle (PHBS). The Ministry of Public Works and Public Housing has introduced PHBS frequently in many programs and activites. WHO declared the virus found in Wuhan, China on $11^{\text {th }}$ March, 2020. At the moment, coronavirus has spread around the world. In Indonesia, the first confirmed case of the virus was declared on March 2nd, 2020. By the time this article was written, there had been 1.667 confirmed cases from 32 provinces $(01 / 02 / 20)$.

The pandemic has slowly helped the government get closer to achieving the goal of the PHBS movement "Due to Covid-19, [the goal of] PHBS can be accomplished faster. Whereas, this has been planned since the 1970s," said Tirta. PHBS itself is a movement or campaign launched by the government consisting of advice to familiarize someone with a clean and healthy lifestyle. The goal of this movement is to create a health-conscious community with knowledge and awareness to live a clean and healthy lifestyle. There are some points of PHBS indicators. Doing physical activity or daily sport, consuming fruits and vegetables, and washing hands with soap are some of PHBS indicators.

The government is responsible for planning, regulating, implementing, fostering, and supervising the implementation of health efforts that are evenly distributed to every layer of the community. However, the government can't work alone so that the role of other parties, including those of business and private sectors is necessary. In making efforts to promote the implementation of PHBS in public places, including temples, the government also needs cooperation with all layers of society.

The PHBS campaign carried out by the Ministry of Health is one of the stimuli given to the public to create a response as desired by the Ministry of Health. This is supported by the Stimulus-Response theory which assumes that a stimulus given to the audience will have a response effect within the audience (Mulyana, 2007).

Many scholars have conducted researches to see stimulus responses, including those of elementary students to an animated video of alertness (Iskandar et al., 2020); the Effect of Online Game (Saputra, 2016); the response to the advertisement (Hardianto, 2019); the Jamaah response to Da'wah (Sakinah et al., 2020); (Fajriani et al., 2020); (Munawaroh et al., 2020); A Response to the Covid-19 pandemic policy education (Robandi et al., 2020).

The phenomenon regarding the PHBS campaign in tackling the Covid-19 pandemic can be studied with the health communication theory, which is the communication between people with the primary focus on how individuals deal with health issues and how they maintain their health. Health communication uses communication to positively influence the health behavior of individuals, families, and communities. Health communication covers information about disease prevention, health promotion, health maintenance policy, and raises individual awareness of health issues, health risks, and health solutions. Advocacy media, mass media, entertainment media, and the internet are various forms of health communication, intending to raise awareness and maintain the degree of health (Thomas, 2006); (Nicely Aken, 2008). Health Communication is very important to educate people during the Covid-19 pandemic (Rimal \& Lapinski, 2009); (Snyder, 2007); (Peng et al., 2020).

During the Covid-19 pandemic, health education is urgently needed in health 
promotion that is closely related to health communication. Some issues are included in the discussion about health, such as Germas or society healthy living movement during the pandemic, clean and healthy lifestyle, ways to maintain health, and ways to deal with diseases. Health communication is persuasive communication, as its objective is to influence and persuade audiences to change their attitude and behavior to start living healthy.

Currently, the millennial generation cannot study and attend classes at their respective campuses. They mostly study at home online, so they live at home for 24 hours. During this Covid-19 pandemic, teenagers must maintain their health and hygiene while carrying out their activities at home. Therefore, to prevent the transmission of the coronavirus, they must live clean and healthy lives, but to what extent do these teenagers realize and practice clean and healthy living habits? Due to the COVID-19 Pandemic, Mercu Buana University (UMB) is also conducting online learning at this time so that all students carry out activities at home every day. However, to what extent are UMB students aware of and behave in a healthy and living manner during this Covid-19 pandemic?

\section{Theoretical Framework}

Social learning theory implies that the stimulus-response theory is a simple learning principle, where the effect is a learning principle that is a reaction to a certain stimulus. Thus, one can explain a close relationship between media, messages and audience reactions. The main elements of this theory are: (a) message (stimulus), (b) a receiver (an organism), and (c) an effect (response) (McQuail, 2016).

The principle of Stimulus-response is the basic theory of the hypodermic needle, a classic theory about the process of strong mass media effect. As explained earlier, the hypodermic theory sees media coverage as drugs injected into the audience's blood vessels and results in expected reaction (McQuail, 2016); (Bungin \& Burhan, 2009).

Health communication includes communication strategies, to convey and influence through the knowledge, attitudes and practices of individuals and communities regarding health care. Health Promotion expressed the health communication which seeks to improve the social climate by encouraging healthy behavior, creating awareness, changing attitudes, and motivating individuals to adopt recommended behaviors (Ishikawa \& Kiuchi, 2010); (Snyder, 2007).

In modern days, health promotion campaigners make use of the rapidly developing digital technology as a communication channel media, which will make it easier to target audiences, adjust messages and engage people in interactive and sustainable exchanges about health (Krishnan $\&$ A. Rahim, 2015) . For example, many of us have come across and encountered billboards, pamphlets, ads that contain the words asking to use a mask, always wash hands with soap in running water, keep your distance and so on (Grier \& Bryant, 2005); (Rimal \& Lapinski, 2009).

The application of effective communication methods and techniques can help convey health messages to the public effectively and able to change their perceptions and behavior towards personal health, their families and their environment. In the current situation, to break the chain of Covid-19 transmission, the strategy carried out will be hard if health education to the public does not exist (Wahyudin \& Uud, 2016); (Ayub et al., 2019). Health educators and all elements are challenged in carrying out education to their families and communities. This is related to health literacy to the community (Karim, 2020); (Emma Mohamad, Nur Afiqah Mohd Haniff, Sabariah Mohamed Salleh, 2015).

The public communication campaign is defined as an effort that is aimed to inform and influence the behavior of a certain group of people in a specific period of time using a series of organized communication activities, including a message composing through various channels to gain the non-commercial benefit of a person and a society (Rice \& Atkin, 2017).

Communication in a campaign involved discussion and idea-sharing between campaigners and the targeted public to persuade a large number of targeted audiences to act on the issue considered urgent to be addressed immediately. Campaign communication is started with a dialogue, emphasizing the long term interaction (H.-D. Klingemann et al., 2011; H.D. A. R. Klingemann, 2002; H.D.

Klingemann \& Römmele, 2011).

The definition of counselling or in the agricultural field commonly mentioned as the extension is a process of social, economic and political change to empower and strengthen the ability of all agribusiness stakeholders through 
a participative learning process, to reach a behavior change of each individual and the society to manage their agribusiness activity to be productive and efficient, for a better and sustainable life and welfare (Setyawan, 2001); (Mardikanto, 2001).

Some of the previous researches about counselling that deal with Clean and Healthy Habits (Andriansyah \& Rahmantari, 2013); (Zukmadani et al., 2020); (Malik et al., 2020); (Handayani et al., 2016); performance and paradigms of counselling (Ismayani, 2019); (Karsidi, 2001); the significance of extension agent toward human behavior (Amanah, 2007).

The communication carried out by PHDI and the Ministry of Health also uses indirect communication to inform and communicate to people by distributing leaflets, pocket note, a tshirt, yoga mattress, that contains information regarding PHBS. The Public Health Office uses media in the form of banners, billboards, posters, and stickers about PHBS information which is distributed to the people.

Anxiety is an emotion that everyone experiences such as feelings of worry, stress and inner turmoil. Although it is almost the same as fear, there are fundamental differences between the two. Direct and objective danger triggers fear, whereas anticipation is the basis of anxiety. Anxiety makes individuals think about everything that might happen or bad things, and this thinking lasts longer than fear (Nieuwland, 2018). According to Hopkins (2015), anxiety is a sign the body is telling you something is wrong in a situation. When a person feels afraid, a reaction occurs under the control of the stimulus. Meanwhile, when someone feels anxious, they are used to experiencing these feelings. Anxiety gives freedom to choose action.

Nevid (2005) describes the aspects of anxiety which consist of physical, behavioral and cognitive aspects as follows: (1) Physical aspects include restless limbs, nervousness, sweating, trembling, dizziness, nausea, difficulty speaking, short breathing, to fast or hard heart beats; (2) Behavioral aspects describe anxiety seen in behavior such as tend to avoid or depend on something restlessly; (3) Cognitive aspects characterized by cognitive changes such as feelings of worry, fear, disturbing fear about the future, fear of losing control, disturbing thoughts that are the same repeatedly, mixed or confused thoughts, difficulty concentrating or focusing thoughts, and thoughts that all things got out of hand.
The anxiety experienced by this teenager will have an impact on; 1) Lack of sleep, anxiety can cause insomnia and other sleep problems (Sohat, Bidjuni, \& Kallo, 2014). The less sleep, the greater the level of anxiety. To overcome sleep deprivation can be done by focusing on ways to improve sleep quality, by increasing sleep quality, it can reduce anxiety. Maintain a consistent bedtime, limit your coffee and alcohol consumption, turn off the alarm, exercise, and stay in the sun every day. Another thing that can be done is to keep the bedroom cool, dark and quiet, and stay away from gadgets to sleep faster; 2) Difficulty focusing, COVID19 has threatened physical and psychological health, and the way of everyday life. Inadvertently, every day you continue to hear various news and then think of ways to protect yourself from the virus. The problem is, while at home you also have to stay focused on studying. As a result of the news of COVID19, the mind becomes unfocused and it is difficult to concentrate on lessons (Hanifah, et al., 2020). The way to increase concentration during this pandemic is to sort what must be done, and don't forget to get enough rest; 3) Often forget, Alexandra Parpura, a gerontologist and founder of Aging Perspectives at the Chevy Chase, explains that anxiety can affect memory. Anything that relaxes the body helps memory, because relaxation involves the parasympathetic nervous system. Good relaxation activities such as exercise can also relax memory. Playing focus-honing games such as crossword puzzles, Sudoku, crafting, playing video games, or playing a musical instrument can also help reduce forgetfulness; 4) Increased irritability and irritability, anxiety can change adolescent emotions such as irritability. Each person's anxiety is different, of course this contributes to irritability and anger. Research shows that anxiety can also trigger these emotions (Hanifah, et al., 2020).

Compliance is a term used to describe the behavior of people in using masks. Compliance is a positive behavior shown by society when they use a mask. The factors that affect adherence depend on many factors, including knowledge, motivation, perception, and belief in disease control, and prevention efforts, variable environment, the quality of health instructions, and ability to access existing resources (Sinuraya et al, 2018). Meanwhile, non-compliance is a condition when an individual or a group of individuals are willing to obey. There are a number of inhibiting factors that affect adherence to advice about 
health ones provided by health personnel (Prihantana et al., 2016). Disobedience is the extent to which the behavior of a person and/or caregiver is in line or not in line with the health promotion plan or therapeutic plan agreed upon by the person (or the giver care) and health care professionals (Wulandari, 2015).

Compliance is closely related to behavior. Notoatmodjo said that there is a theory put forward by Lawrence Green about human behavior. There are three factors that caused a behavior, namely predisposing factors, enabling factors and driving factors. This theory studies human behavior in terms of health which can be used in diagnosing health problems and as a health planning tool.

\section{Material and Methodology}

This research uses a paradigm with positivistic paradigm. The method used quantitative explanatory survey. This research used a questionnaire to obtain the primary data.

In general, understanding of the study population can be made based on the determination of data sources. According to Burhan Bungin (Bungin, 2005), populations can be divided into limited populations and infinite populations. The definition of a limited population is a population that has quantitative data sources that have quantitative limits. The population used in this study is limited a population and will be the subject of research, namely students of the graduate school of Universitas Mercu Buana Jakarta.

Sampling in this study uses a purposive technique. This technique used for selecting samples is specifically based on research objectives. The number of active students at the Faculty of Communication Sciences UMB in $2020 / 2021$ is 4,168. This study used Slovin formula to determine the sample size of 196 respondents, with a sampling error of $10 \%$ and confidence level of 99.8 percent.. The number of samples was limited to 100 students. The sample size of 196 respondents was determined directly and purposely since the population was not exactly known. This sampling technique was chosen based on certain considerations.

This research used the technique by distributing 100 questionnaires. Meanwhile, secondary data were obtained from various references, both books and digital media.

In this study, the data analysis technique was used to test the hypothesis. The inferential statistical tests answered the hypothesis testing with correlation tests and simple regression tests
In more detail, the hypothesis of this research is: (1) H0. There is no impact of the PHBS Campaign between the Anxiety level and compliance level; (2) Ha. There is an impact of the PHBS Campaign between on the Anxiety level and compliance level.

\section{Result and Discussion}

The results of this study are explained starting with the identities of respondents, the results of the validity test, hypothesis testing and hypothesis testing using PLS. The descriptions of the research results are as follows: More respondents were male $(79.1 \%)$ than female $(20.9 \%)$. Most of the respondents study Public Relations (79.6\%), Marketing Communication (13.8\%), Broadcasting (5.5\%), and Digital Communication (1.3\%). Most respondents received information about Covid19 from Instagram (82.7\%), Television (66.3\%), Youtube and Twitter (41.8\%), News Portal (40.3\%), WhatsApp (35.2 \%), Line $(23 \%)$. Most respondents received information about a clean and healthy lifestyle during the Covid-19 pandemic from Instagram (79.6\%), Television (54.1\%), Youtube (46.4\%), Twitter (40.3\%), Portal News (34.7\%), WhatsApp (31.6\%), Line $(21.9 \%)$.

The majority of respondents knew they had to use personal protection every day and respondents only knew about personal protection using a mask $(98.5 \%)$. Respondents know that the use of protection is only 2 personal protective equipment $(43.4 \%), 3$ protective equipment $(29.6 \%), 3$ personal protective equipment (21.9\%). Respondents understand when they leave the house they only touch important things $(80.1 \%)$, and touch all objects as usual (12.5\%). Respondents understand the objects they should avoid touching during the pandemic; banknotes (47.4\%), others $\quad(42.9 \%) . \quad$ Respondents understand they should bring a hand sanitizer when leaving the house: always $(68.9 \%)$, often (16.3\%), sometimes (8.2\%). Respondents understand what they should do after carrying out activities outside the home, namely: Washing hands with soap (48.5\%), Bathing $(42.3 \%)$. Respondents understand they should not touch family members before cleaning $(83.7 \%)$ and agree $(15.8 \%)$.

Respondents understand they should wash their hands with soap after receiving objects and food from outside $(41.8 \%)$, before eating (39.3\%), before touching the face $(13.8 \%)$. Respondents understand they should follow SOPs when washing hands (64.8\%), 
follow most of the SOP (30.1\%). Respondents understand the information conveyed is about the obligation to wash hands and live clean $(72.4 \%)$, and others also agree (27\%). Respondents understand that during the Covid 19 pandemic, they should consume 1-2 servings of vegetables and fruit per day (81.1\%), 3-4 servings per day (13.3\%). Respondents understand during the Covid-19 pandemic they should exercise for 5-10 minutes per/ day (50.5\%), 11-20 minutes per day (16.3\%) and never $(16.3 \%)$ for more than 30 minutes per day $(9.2 \%)$. Respondents understand during the Covid-19 pandemic, they should bask in the sun for 5-10 minutes per day (49\%), some say never (24\%), 11-20 minutes (18.9\%). Respondents understand during the Covid-19 pandemic they should rest and sleep for 8 hours per day $(44.9 \%)$, less than 8 hours per day $(38.8 \%)$, more than 8 hours per day (16.3\%).

Respondents stated that after reading information about Covid 19 they feel it necessary to try to improve the quality of their sleep (78.1\%), lack of sleep (9.7\%). Respondents stated that after reading information about Covid 19 they feel they stay unfocused $(38.3 \%)$, have difficulty focusing on something (37.2\%), have difficulty concentrating on lessons (24.5\%). Respondents stated that after reading information about Covid 19, they sometimes forget (64.8\%), the body became tense $(28.1 \%)$, and had difficulty remembering $(7.1 \%)$. Respondents stated that after reading information about Covid-19 they feel irritable $(41.8 \%)$, irritable $(10.9 \%)$, easy to laugh $(11.7 \%)$, easy to cry $(15.8 \%)$, easily cranky $(9,7 \%)$. Respondents stated that they overcome their anxiety by praying/worshiping (43.4\%), listening to music (20.4\%), watching movies (19.4\%), playing games (10.2\%).

Some respondents stated that they adhere to the health protocols every day: strongly agree $(69.9 \%)$ and agree (30.1\%). More than half of the respondents stated that the causes of complying with health protocols were: themselves (68.4\%), parents $(16.8 \%)$ and the environment (14.8\%). Most of the respondents stated that the motivation to comply with the health protocols was to stay healthy $(74.5 \%)$, so as not to become infected (24\%). Respondents stated that information factors that lead to compliance with health protocols are that information about the benefits of health protocols is clear $(87.2 \%)$, information about the benefits of health protocols is presented in various media (54.6\%), information about the consequences of health protocols is clear (33, $7 \%$ ). The majority of respondents know what $5 \mathrm{M}$ stands for and means, not just $3 \mathrm{M}$ in adhering to health protocols $(92.9 \%)$.

This stage is related to the formation of a structural equation model, before estimating. This model is formulated based on a theory or previous research.

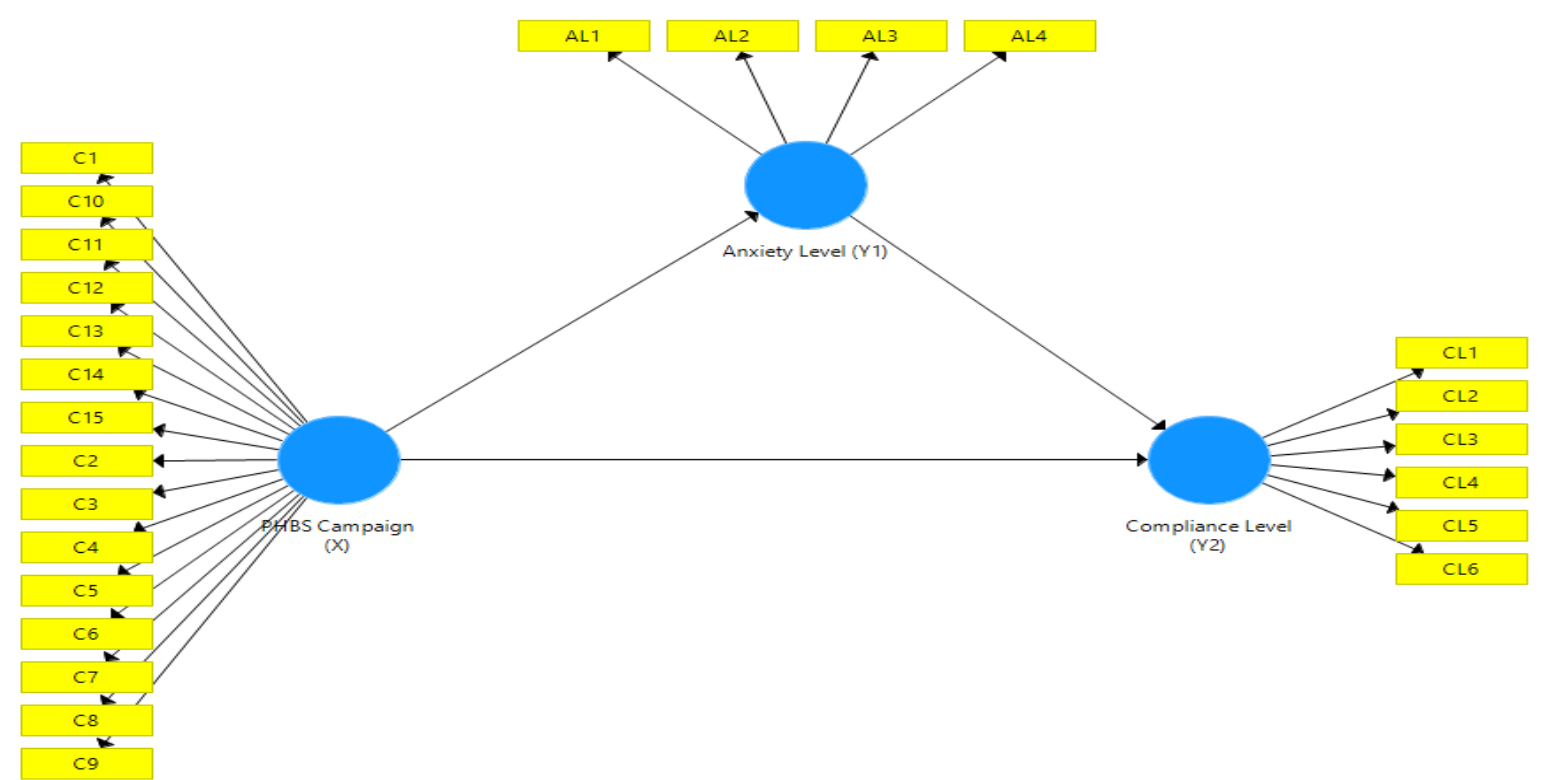

Picture 1. Partial Least Square Conceptual Model Diagram 
The process of estimating the aforementioned model is carried out with the help of the SmartPLS 3.0 application program.

The first stage assesses the criteria for convergent validity. An indicator will be said to have good validity if it has a loading factor value greater than 0.70 . While the loading factor of 0.50 to 0.60 can still be maintained for models that are still in the development stage (Ghozali, 2014: 39). Based on the estimation results using the help of the SmartPLS 3 application program, the following output are obtained.

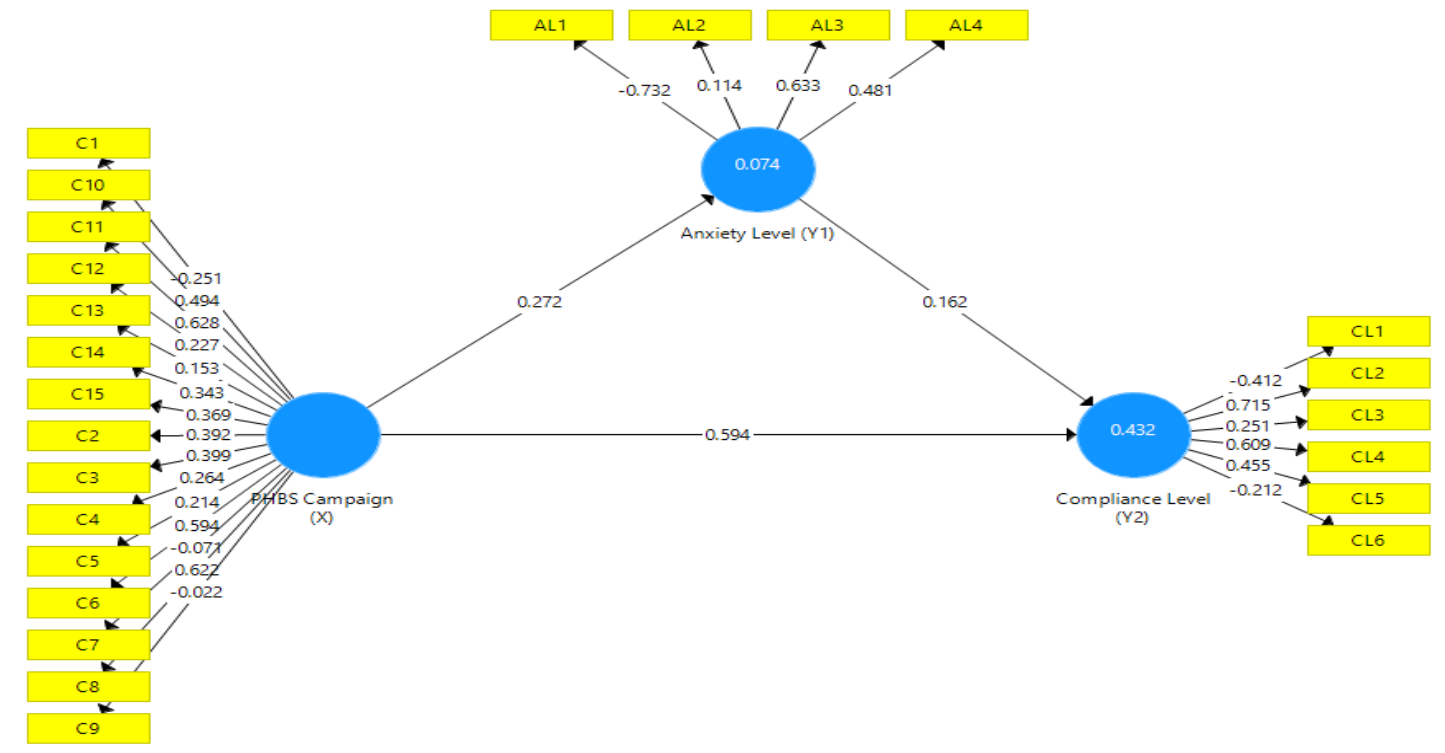

Picture 2. Outer Model Evaluation Loading Factor Values Diagram

Source: Data Processing (2021)

Based on the results of testing with SmartPLS 3.0, the following results were obtained.

Table 2. Loading Factor

\begin{tabular}{|c|c|c|c|}
\hline Construct Variable & $\begin{array}{l}\text { Loading } \\
\text { Factor }\end{array}$ & $\begin{array}{c}\mathbf{R} \\
\text { kritis }\end{array}$ & $\begin{array}{c}\text { Criteria } \\
\text { (Loading } \\
\text { Factor } \geq \\
0.5 \text { ) }\end{array}$ \\
\hline $\begin{array}{l}\text { C1 <- PHBS Campaign } \\
\text { (X) }\end{array}$ & -0.251 & 0,5 & Invalid \\
\hline $\begin{array}{l}\mathrm{C} 2<- \text { PHBS Campaign } \\
(\mathrm{X})\end{array}$ & 0,392 & 0,5 & Invalid \\
\hline $\begin{array}{l}\text { C3 <- PHBS Campaign } \\
(\mathrm{X})\end{array}$ & 0,399 & 0,5 & Invalid \\
\hline $\begin{array}{l}\text { C4<- PHBS Campaign } \\
\text { (X) }\end{array}$ & 0,264 & 0,5 & Invalid \\
\hline $\begin{array}{l}\text { C5 <- PHBS Campaign } \\
(\mathrm{X})\end{array}$ & 0,214 & 0,5 & Invalid \\
\hline $\begin{array}{l}\text { C6 <- PHBS Campaign } \\
(\mathrm{X})\end{array}$ & 0,594 & 0,5 & Valid \\
\hline $\begin{array}{l}\text { C7 <- PHBS Campaign } \\
(\mathrm{X})\end{array}$ & $-0,071$ & 0,5 & Invalid \\
\hline $\begin{array}{l}\text { C8 <- PHBS Campaign } \\
\text { (X) }\end{array}$ & 0,622 & 0,5 & Valid \\
\hline $\begin{array}{l}\text { C9 <- PHBS Campaign } \\
(\mathrm{X})\end{array}$ & $-0,022$ & 0,5 & Invalid \\
\hline $\begin{array}{l}\text { C10<- PHBS Campaign } \\
(\mathrm{X})\end{array}$ & 0,494 & 0,5 & Invalid \\
\hline $\begin{array}{l}\text { C11<- PHBS Campaign } \\
\text { (X) }\end{array}$ & 0,628 & 0,5 & Valid \\
\hline
\end{tabular}




\begin{tabular}{|c|c|c|c|}
\hline Construct Variable & $\begin{array}{l}\text { Loading } \\
\text { Factor }\end{array}$ & $\begin{array}{c}\text { R } \\
\text { kritis }\end{array}$ & $\begin{array}{c}\text { Criteria } \\
\text { (Loading } \\
\text { Factor } \geq \\
\text { 0.5) }\end{array}$ \\
\hline $\begin{array}{l}\text { C12<- PHBS Campaign } \\
\text { (X) }\end{array}$ & 0,227 & 0,5 & Invalid \\
\hline $\begin{array}{l}\text { C13<- PHBS Campaign } \\
(\mathrm{X})\end{array}$ & 0,153 & 0,5 & Invalid \\
\hline $\begin{array}{l}\text { C14 <- PHBS Campaign } \\
(\mathrm{X})\end{array}$ & 0,343 & 0,5 & Invalid \\
\hline $\begin{array}{l}\text { C15 <- PHBS Campaign } \\
(\mathrm{X})\end{array}$ & 0,369 & 0,5 & $\begin{array}{c}\text { Not } \\
\text { Valid }\end{array}$ \\
\hline $\begin{array}{l}\text { AL1 <- Anxiety Level } \\
\text { (Y1) }\end{array}$ & $-0,732$ & 0,5 & Invalid \\
\hline $\begin{array}{l}\text { AL2 <- Anxiety Level } \\
\text { (Y1) }\end{array}$ & 0,114 & 0,5 & Invalid \\
\hline $\begin{array}{l}\text { AL3 <- Anxiety Level } \\
\text { (Y1) }\end{array}$ & 0,633 & 0,5 & Valid \\
\hline $\begin{array}{l}\text { AL4 <- Anxiety Level } \\
\text { (Y1) }\end{array}$ & 0,481 & 0,5 & Invalid \\
\hline $\begin{array}{l}\text { CL1 <- Compliance } \\
\text { Level (Y2) }\end{array}$ & $-0,412$ & 0,5 & Invalid \\
\hline $\begin{array}{l}\text { CL2 <- Compliance } \\
\text { Level (Y2) }\end{array}$ & 0,715 & 0,5 & Valid \\
\hline $\begin{array}{l}\text { CL3 <- Compliance } \\
\text { Level (Y2) }\end{array}$ & 0,251 & 0,5 & Invalid \\
\hline $\begin{array}{l}\text { CL4 <- Compliance } \\
\text { Level (Y2) }\end{array}$ & 0,609 & 0,5 & Valid \\
\hline $\begin{array}{l}\text { CL5 <- Compliance } \\
\text { Level (Y2) }\end{array}$ & 0,455 & 0,5 & Invalid \\
\hline $\begin{array}{l}\text { CL6 <- Compliance } \\
\text { Level (Y2) }\end{array}$ & $-0,212$ & 0,5 & Invalid \\
\hline
\end{tabular}

Source: Data Processing (2021)

Table 2. shows the loading factor value for each construct of each variable. Based on the table, it can be seen that the majority of the loading factor is less than 0.5 . So it can be concluded that based on each construct in the study it has poor validity. However, due to the consideration that all indicators are important to explain the model, all indicators are still used in this research model.
Furthermore, the Average Variance Extracted (AVE) Test will be carried out to further strengthen the results of convergent validity with the criteria if the AVE value is $>$ 0.5 , then the construct used in the study is valid. The following shows the results of the average variance extracted test using the PLS 3.0 program:

Table 3. Average Variance Extracted

\begin{tabular}{|l|c|c|c|}
\hline \multicolumn{1}{|c|}{ Laten } & $\begin{array}{c}\text { Average } \\
\text { Variance } \\
\text { Extracted (AVE) }\end{array}$ & R Critical & $\begin{array}{c}\text { Criteria } \\
(\boldsymbol{A V E} \geq \mathbf{0 . 5})\end{array}$ \\
\hline PHBS Campaign (X) & 0,147 & 0,5 & Valid \\
\hline Anxiety Level (Y1) & 0,295 & 0,5 & Valid \\
\hline Compliance Level (Y2) & 0,228 & 0,5 & Valid \\
\hline
\end{tabular}

Source: Data Processing (2021) 
Based on Table 3. It can be seen that the convergent validity results are based on the average variance extracted. These results indicate that all latent variables have AVE values that are less than 0.5 . This indicates that the indicators that form the latent construct have poor convergent validity when viewed from the average variance extracted value. However, due to the consideration that all indicators are important to explain the model, all indicators are still used in this research model.

Discriminant Validity can be seen from the cross-loading value. The correlation value of an indicator with its construct must be greater than the correlation value between indicators and other constructs. In addition, the comparison between the square root of AVE and the correlation between latent constructs shows the discriminant validity. If the square root value of AVE is greater than the correlation between latent constructs, it indicates that the latent constructs have a good discriminant validity in the model (Fornell and Larcker, 1981). The following shows the results of discriminant validity testing using the Smart PLS 3.0 program.

Table 4. Cross-Loading Discriminant Validity Test Value

\begin{tabular}{|l|r|r|r|}
\hline & $\begin{array}{c}\text { Anxiety } \\
\text { Level } \\
\text { (Y1) }\end{array}$ & $\begin{array}{c}\text { Compliance } \\
\text { Level (Y2) }\end{array}$ & $\begin{array}{c}\text { PHBS } \\
\text { Campaign } \\
\text { (X) }\end{array}$ \\
\hline AL1 & $-0,732$ & $-0,257$ & $-0,174$ \\
\hline AL2 & 0,114 & $-0,015$ & 0,115 \\
\hline AL3 & 0,633 & 0,232 & 0,147 \\
\hline AL4 & 0,481 & 0,103 & 0,179 \\
\hline C1 & $-0,112$ & $-0,134$ & $-0,251$ \\
\hline C10 & 0,116 & 0,396 & 0,494 \\
\hline C11 & 0,131 & 0,424 & 0,628 \\
\hline C12 & 0,136 & 0,083 & 0,227 \\
\hline C13 & 0,067 & 0,034 & 0,153 \\
\hline C14 & 0,088 & 0,152 & 0,343 \\
\hline C15 & 0,117 & 0,290 & 0,369 \\
\hline C2 & 0,008 & 0,202 & 0,392 \\
\hline C3 & 0,180 & 0,197 & 0,399 \\
\hline C4 & 0,067 & 0,099 & 0,264 \\
\hline C5 & 0,044 & 0,129 & 0,214 \\
\hline C6 & 0,128 & 0,424 & 0,594 \\
\hline C7 & 0,174 & $-0,024$ & $-0,071$ \\
\hline C8 & 0,171 & 0,343 & 0,622 \\
\hline C9 & $-0,148$ & $-0,021$ & $-0,022$ \\
\hline CL1 & $-0,265$ & $-0,412$ & $-0,196$ \\
\hline CL2 & 0,134 & 0,715 & 0,563 \\
\hline CL3 & 0,120 & 0,251 & 0,120 \\
\hline CL4 & 0,221 & 0,609 & 0,329 \\
\hline CL5 & 0,130 & 0,455 & 0,241 \\
\hline CL6 & $-0,150$ & $-0,212$ & $-0,114$ \\
\hline
\end{tabular}

Source: Data Processing (2021)
Based on Table 4. It can be seen that only a few indicators have a high correlation to their constructs compared to other constructs. So it can be concluded that the research model has a poor discriminant validity on the discriminant validity cross loading.

The next stage assesses Cronbach's Alpha and Composite Reliability criteria. Each construct will be said to be reliable if it has Cronbach's Alpha and Composite Reliability that is greater than 0.70 (Ghozali, 2014: 40). The following shows the results of the reliability test using the Smart PLS 3.0 program.

Table 5. Cronbach's Alpha and Composite Reliability

\begin{tabular}{|l|c|c|}
\hline \multicolumn{1}{|c|}{ Latent } & $\begin{array}{c}\text { Cronbach' } \\
\text { s Alpha }\end{array}$ & $\begin{array}{c}\text { Composite } \\
\text { Reliability }\end{array}$ \\
\hline $\begin{array}{l}\text { PHBS Campaign } \\
\text { (X) }\end{array}$ & 0.436 & 0.597 \\
\hline $\begin{array}{l}\text { Anxiety Level } \\
\text { (Y1) }\end{array}$ & -0.147 & 0.080 \\
\hline $\begin{array}{l}\text { Compliance } \\
\text { Level (Y2) }\end{array}$ & 0.006 & 0.299 \\
\hline
\end{tabular}

Source: Data Processing (2021)

Based on Table 5. It can be seen that all latent constructs have a Cronbach's alpha value of less than 0.7, this indicates that the latent constructs have poor reliability. In addition, on the composite reliability value, all latent constructs also have a value of less than 0.70 which indicates that the latent construct has poor reliability.

Inner model evaluation is an analysis of the results of the relationship between constructs. The estimated relationship between constructs can be seen as follows.

- The latent variable PHBS Campaign (X) influences the latent variable Anxiety Level (Y1).

- The latent variable PHBS Campaign (X) influences the latent variable Compliance Level (Y2) through the latent variable Anxiety Level (Y1).

Furthermore, based on the results of testing with SmartPLS 3., the following R Square results are obtained.

Table 6. R Square

\begin{tabular}{|l|c|c|}
\hline & R Square & $\begin{array}{c}\text { Relationship } \\
\text { Strength }\end{array}$ \\
\hline Anxiety Level (Y1) & 0,074 & Weak \\
\hline Compliance Level (Y2) & 0,432 & Moderate \\
\hline \multicolumn{2}{|c|}{ Source: Data Processing (2021) }
\end{tabular}


According to Chin (1998) in Ghozali, I \& Latan, H (2015: 81), R Square Adjusted with a value of 0.67 indicates a strong model, a value of 0.33 indicates a moderate model and a value of 0.19 indicates a weak model.

From the results of Table 6 , it can be seen that the R-Square for the Anxiety Level (Y1) variable is 0.074 , which indicates the PHBS Campaign (X) contributes 0.074 or $7.4 \%$ to the Anxiety Level (Y1). While the remaining $92.6 \%$ is the influence of other factors that are not observed.

The R-Square for the Compliance Level (Y2) variable is 0.432 , which means that the PHBS Campaign (X) contributes an influence of 0.432 or $43.2 \%$ on Compliance Level (Y2) through the latent Anxiety Level (Y1) variable. While the remaining $56.8 \%$ is the influence of other factors that are not observed.

Next is to look at the F Square value. In the book Ghozali and Latan (2015: 81) it is explained that $\mathrm{F}$ Square is used to see the effect of predictors of latent variables at the structural level. The F Square value of 0.02 indicates a small rating, an Effect Size of 0.15 indicates a medium rating and an Effect Size of 0.35 indicates a large rating. Based on the results of testing with SmartPLS 3, the F Square results are as follows.

Table 7. F Square

\begin{tabular}{|l|c|c|}
\hline \multicolumn{1}{|c|}{ Variabel } & $\begin{array}{c}\text { Effect } \\
\text { Size }\end{array}$ & Rating \\
\hline PHBS Campaign $(\mathrm{X})$ & 0,576 & High \\
\hline Anxiety Level $(\mathrm{Y} 1)$ & 0,043 & Low \\
\hline
\end{tabular}

Source: Data Processing (2021)

Table 7. shows that the PHBS Campaign variable $(\mathrm{X})$ has a large category of influence in influencing Compliance Level (Y2), and the PHBS Campaign variable (X) has a small category influence in affecting Compliance Level (Y2) through the latent variable Anxiety Level (Y1).

The next step is to look at the Q-square predictive relevance for the construct model. The researcher used the Q-square test to measure how well the observation value generated by the model and also its parameter estimation. The Q-square value is more different than 0 (zero) indicating that the model has a predictive relevance value, while the Qsquare value is less than 0 (zero) indicating that the model has less predictive relevance (Ghozali, 2014: 41). The Q-square value obtained using the R2 value in the table above, the following calculation results are obtained:
Table 8. $Q^{2}$ Predictive Relevance

\begin{tabular}{|l|c|c|}
\hline \multicolumn{1}{|c|}{ Variable } & $\begin{array}{c}\mathbf{R} \\
\text { Square }\end{array}$ & $\begin{array}{c}\mathbf{1 - R} \\
\text { Square }\end{array}$ \\
\hline Anxiety Level $(\mathrm{Y} 1)$ & 0,074 & 0,926 \\
\hline Compliance Level $(\mathrm{Y} 2)$ & 0,432 & 0,568 \\
\hline $\mathrm{Q}^{2}=$ & $\begin{array}{c}\mathrm{Q}^{2}=1-\left(1-\mathrm{R}_{1}^{2}\right)\left(1-\mathrm{R}_{2}^{2}\right) \\
=0,474\end{array}$ \\
\hline Galat $=$ & \multicolumn{2}{|c|}{$\begin{array}{c}52,6 \% \\
52\end{array}$} \\
\hline
\end{tabular}

Source: Data Processing (2021)

Based on the results of the above calculations, it is known that the value of $\mathrm{Q}$ square is greater than 0 which indicates the observed values have been reconstructed well so that the model has predictive relevance. This Q square value can also be used to see the relative effect of the structural model on observational measurements for endogenous latent variables. This means that there is 0.474 or $47.4 \%$ relative effect of the structural model on the observation measurement of endogenous latent variables, and as much as $52.6 \%$ is the model error.

Hypothesis testing in this study was carried out using the path coefficient, t-value, and $\mathrm{p}$-value. To assess the significance and predictions in hypothesis testing, it can be seen from the path coefficient and t-value (Abdillah \& Hartono, 2015: 197). According to Abdillah \& Hartono (2015: 211), assessing predictions and significance in hypothesis testing can be seen from the $\mathrm{t}$-value and $\mathrm{p}$-value. The $\mathrm{t}$-table value can be seen in the following table:

Table 9. T-tabel Value

\begin{tabular}{|c|c|c|}
\hline & One tailed & Two tailed \\
\hline t-tabel & 1.64 & 1.96 \\
\hline \multicolumn{3}{|c|}{ Source: Abdillah \& Hartono (2015: 211) }
\end{tabular}

According to Abdillah \& Hartono (2015: 211 ), with a confidence level of $95 \%$ (alpha $5 \%$ ), two tailed, the t-table value is obtained as follows:

1. If the t-statistic value $>1.96$ (used for direct effect), then $\mathrm{H} 0$ is rejected and $\mathrm{H} 1$ is accepted. 2 . If the $t$-statistic value $<1.96$ (used for direct effect), then $\mathrm{H} 0$ is accepted and $\mathrm{H} 1$ is rejected.

The magnitude of the significance value between the variables tested is presented in the form of the value contained in the arrow that connects one of the variables to the variable being the goal. 


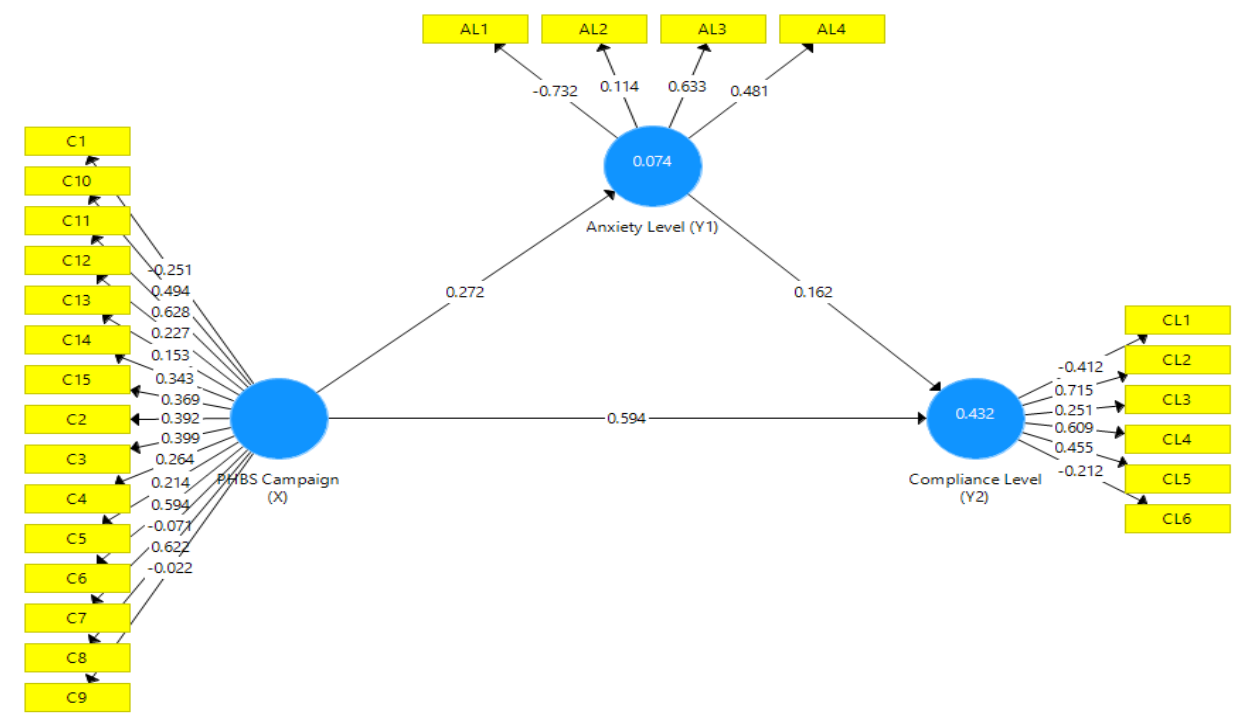

Picture 4. Structural Model (coeficient path, beta)

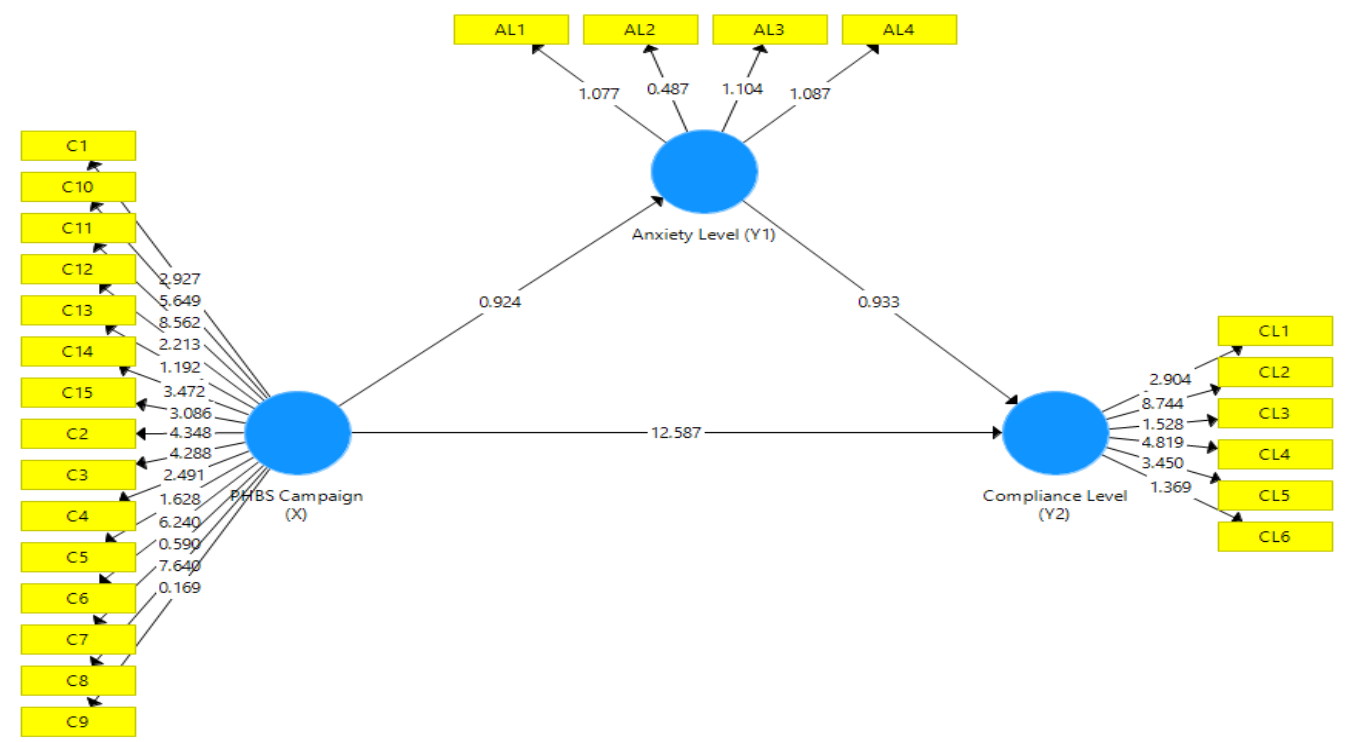

Picture 5. Significant Value (t-count)

Source: Output data processing using Smart PLS (2021)

Research hypothesis 1 reads: The PHBS Campaign has a significant effect on Anxiety Level. And from this hypothesis it is developed into a statistical hypothesis as follows:

H0: PHBS Campaign has no significant effect on the Anxiety Level;

H1: PHBS Campaign has a significant effect on the Anxiety Level.
Furthermore, based on the above hypotheses, hypothesis testing was carried out using the bootstrapping method using SmartPLS software, and the values were obtained as follows:

Table 10. Path Coefficient and the t-count Effect of the PHBS Campaign (X) on Anxiety Level (Y1)

\begin{tabular}{|c|c|c|c|c|}
\hline & $\begin{array}{c}\text { Original } \\
\text { Sample (O) }\end{array}$ & t-Statistic & p-value & Result \\
\hline $\begin{array}{c}\text { PHBS Campaign } \\
\text { (X) on Anxiety } \\
\text { Level (Y1) }\end{array}$ & 0,272 & 0,924 & 0,356 & $\begin{array}{c}\text { Accept } \\
\mathrm{H}_{0}\end{array}$ \\
\hline
\end{tabular}

Source: Data Processing (2021) 
From the results of Table 10 above, the Original Sample $(O)$ value is 0.272 , indicating that the direction of the effect of the PHBS Campaign on Anxiety Level is positive or unidirectional, meaning that if the PHBS Campaign increases, the Anxiety Level will also increase. The effect of the PHBS Campaign on Anxiety Level is not significant, with a tstatistic value of 0.924 smaller than the $t$ table or $0.924<1.96$, and a p value of 0.356 greater than alpha $5 \%(0.05)$. Thus, H1 is rejected, meaning that the PHBS Campaign has no significant effect on Anxiety Level.

Research hypothesis 2 reads: PHBS Campaign has a significant effect on
Compliance Level. And from this hypothesis it is developed into a statistical hypothesis as follows:

H0: PHBS Campaign has no significant effect on Compliance Level;

H1: PHBS Campaign has a significant effect on Compliance Level.

Furthermore, based on the above hypotheses, hypothesis testing was carried out using the bootstrapping method using SmartPLS software, and the values were obtained as follows:

Table 11. Path Coefficient and the t-count Effect of PHBS Campaign (X) on the Compliance Level (Y2)

\begin{tabular}{|c|c|c|c|c|}
\hline & $\begin{array}{c}\text { Original } \\
\text { Sample } \\
\text { (O) }\end{array}$ & $\begin{array}{c}\mathbf{t}- \\
\text { Statistik }\end{array}$ & $\begin{array}{c}\boldsymbol{p} \text { - } \\
\text { value }\end{array}$ & Result \\
\hline $\begin{array}{c}\text { PHBS } \\
\text { Campaign }\end{array}$ & & & & \\
$\begin{array}{c}\text { (X) against } \\
\text { Compliance } \\
\text { Level (Y2) }\end{array}$ & 0,594 & 12,587 & 0,000 & $\begin{array}{c}\text { Reject } \\
\mathrm{H}_{0}\end{array}$ \\
\hline
\end{tabular}

Source: Data Processing (2021)

From the results of Table 11. above, the Original Sample $(\mathrm{O})$ value is 0.594 , which indicates the direction of the PHBS Campaign's influence on the Compliance Level is positive or unidirectional, which indicates if the PHBS Campaign increases, the Compliance Level will also increase. The effect of the PHBS Campaign on Compliance Level is significant, with a tstatistic value of 12.587 greater than the t table or $12.587>1.96$, and a $p$ value of 0.000 smaller than alpha $5 \%(0.05)$. Thus, H1 is accepted, meaning that the PHBS Campaign has a significant effect on Compliance Level.

Research hypothesis 3 reads: Anxiety Level has a significant effect on Compliance
Level. And from this hypothesis it is developed into a statistical hypothesis as follows:

H0: Anxiety Level has no significant effect on Compliance Level;

H1: Anxiety Level has a significant effect on Compliance Level.

Furthermore, based on the above hypotheses, hypothesis testing was carried out using the bootstrapping method using SmartPLS software, and the values were obtained as follows:

Table 12. Path Coefficient and the t-count Effect of Anxiety Level (Y1) on Compliance Level (Y2)

\begin{tabular}{|c|c|c|c|c|}
\hline & $\begin{array}{c}\text { Original } \\
\text { Sample } \\
\text { (O) }\end{array}$ & $\begin{array}{c}\mathbf{t}- \\
\text { Statistik }\end{array}$ & $\begin{array}{c}\boldsymbol{p} \text { - } \\
\text { value }\end{array}$ & Result \\
\hline $\begin{array}{c}\text { Anxiety } \\
\text { Level (Y1) } \\
\text { on }\end{array}$ & 0,162 & 0,933 & 0,351 & $\begin{array}{c}\text { Accept } \\
\mathrm{H}_{0}\end{array}$ \\
$\begin{array}{c}\text { Compliance } \\
\text { Level (Y2) }\end{array}$ & & & & \\
\hline
\end{tabular}

Source: Data Processing (2021) 
From the results of Table 12. above, the Original Sample (O) value is 0.162 which indicates the direction of the influence of Anxiety Level on Compliance Level is positive or unidirectional which indicates if Anxiety Level increases, Compliance Level will also increase. The effect of Anxiety Level on Compliance Level is not significant, with a tstatistic value of 0.933 which is smaller than the $\mathrm{t}$ table or $0.933<1.96$, and a $\mathrm{p}$ value of 0.351 which is greater than alpha $5 \%(0.05)$. Thus, $\mathrm{H} 1$ is rejected, meaning that Anxiety Level has no significant effect on Compliance Level.

Research hypothesis 4 reads: PHBS Campaign has a significant effect on
Compliance Level through Anxiety Level. And from this hypothesis it is developed into a statistical hypothesis as follows:

H0: PHBS Campaign has no significant effect on Compliance Level through Anxiety Level;

H1: The PHBS Campaign has a significant effect on Compliance Level through Anxiety Level.

Furthermore, based on the above hypotheses, hypothesis testing was carried out using the bootstrapping method using SmartPLS software, and the values were obtained as follows:

Table 13. Path Coefficient and t-calculate the Effect of the PHBS Campaign on Compliance Level through Anxiety Level

\begin{tabular}{|c|c|c|c|l|}
\hline & $\begin{array}{c}\text { Original } \\
\text { Sample } \\
\text { (O) }\end{array}$ & $\begin{array}{c}\mathbf{t}- \\
\text { Statist } \\
\text { ics }\end{array}$ & $\begin{array}{c}\boldsymbol{p} \text { - } \\
\text { value }\end{array}$ & Result \\
\hline $\begin{array}{c}\text { PHBS } \\
\text { Campaign } \\
\text { towards } \\
\begin{array}{c}\text { Compliance } \\
\text { Level through } \\
\text { Anxiety Level }\end{array}\end{array}$ & 0,044 & 1,675 & 0,095 & $\begin{array}{l}\text { Accept } \\
\mathrm{H}_{0}\end{array}$ \\
\hline
\end{tabular}

Source: Data Processing (2021)

From the results of Table 13. above, the Original Sample $(\mathrm{O})$ value obtained is positive, namely 0.044. The effect of the PHBS Campaign on Compliance Level through Anxiety Level is not significant, with a tstatistic value of 1.675 smaller than the t table or $1.675<1.96$, and a $p$ value of 0.095 greater than alpha $5 \%(0.05)$. Thus, H1 is rejected, meaning that the PHBS Campaign has no significant effect on Compliance Level through Anxiety Level.

Based on the research results, it is known that the PHBS Campaign has no significant effect on Anxiety Level. This can be seen from the information content that provides guidance on hygiene and healthy living habits in the campaign. Information instructions regarding clean and healthy living habits do not cause people to be anxious, but instead they become calm in carrying out their daily lives behind the threat of the Covid 19 virus which can attack those who can cause infection and even death.

This is in accordance with the theory of health communication, that people need information about health and the task of the government is to provide health campaigns and educate people to live clean and healthy during the pandemic. The results of this study refute the research

PHBS Campaign has a significant effect on Compliance Level. This can be seen from the opinion of respondents who stated that understanding the contents of the campaign message to have a clean and healthy lifestyle would avoid the threat of contracting the Covid 19 virus. Therefore, respondents understand and comply with the Health protocol according to the content of the PHBS campaign. This is consistent with research on adherence to the Covid-19 Health protocol in Nigeria (Olapegba et al., 2020); adherence to public services to keep up with new innovations (Tucker \& United Nations Development Programme, 2014).

Anxiety Level has no significant effect on Compliance Level. Respondents considered that the level of anxiety about the threat of the covid virus came from negative messages obtained from the environment and content on television. The level of public compliance to behave in a clean and healthy life is based on public awareness that avoiding the threat of Covid 19 is by living clean and healthy, instead of the Anxiety level. In fact, the level of anxiety will reduce the human body's immunity which will lead to contracting the Covid 19 virus. 
The health communication theory (Thomas, 2006), and the results of research on campaigns for children on the level of anxiety about child abuse (L.Gibson et al., 2017) supported the idea; Covid 19 can affect mental health, risk factors and social media in Wuhan, China (Wang et al., 2020).

PHBS Campaign has no significant effect on Compliance Level through Anxiety Level. The government is tasked with providing education to the public to survive in the current pandemic era. The government carries out a campaign for clean and healthy living habits through various media so that the public can comply with Health protocols so that they can avoid the threat of the Covid 19 virus. The level of community anxiety has no effect on the level of compliance with the Health protocols, this is because the level of anxiety is not a factor that causes the level of community compliance, but the factor of the desire to live clean and healthy to avoid the threat of the Covid 19 virus.

This is in accordance with the social learning theory (Yanuardianto, 2019); (McQuail, 2016), The community learns about the clean and healthy living campaign with the aim of surviving in the current pandemic era and can accept it by complying with the contents of the information content so that they can comply with the Health protocol and live a clean and healthy life.

\section{Conclusions}

From the results of calculations and analyzes that have been carried out in the previous chapter, it can be concluded: PHBS Campaign has no significant effect on Anxiety Level. PHBS Campaign has a significant effect on Compliance Level. Anxiety Level has no significant effect on Compliance Level. PHBS Campaign has no significant effect on Compliance Level through Anxiety Level.

Suggestions that researchers can provide based on the results of this study include: The campaign is being carried out more creatively with a variety of key messages as well. It is hoped that the Ministry of Health can maintain or even increase creativity and innovation in the next campaign appearance.

\section{References}

Amanah, S. (2007). Makna Penyuluhan dan Transformasi Perilaku Manusia. Jurnal Penyuluhan.

https://doi.org/10.25015/penyuluhan.v3i1 .2152

Andriansyah, Y., \& Rahmantari, D. N. (2013).
Penyuluhan Dan Praktik Phbs ( Perilaku Hidup Bersih. Inovasi Dan Kewirausahaan.

Ayub, S. H., Hassim, N., Yahya, A. H., Hamzah, M., \& Bakar, M. Z. A. (2019). Exploring the characteristics of healthy lifestyle campaign on social media: A case study on FIT Malaysia. Jurnal Komunikasi: Malaysian Journal of Communication.

https://doi.org/10.17576/JKMJC-20193504-20

Bungin, B. (2005). Data Penelitian Kuantitatif. PT Raja Grafindo. Jakarta, 2005.

Bungin, \& Burhan. (2009). Sosiologi Komunikasi: Teori, Paradigma, dan Diskursus Teknologi Komunikasi di Masyarakat. Kencana Prenada Media Group. $\quad$ https://doi.org/10.1186/17585996-1-20

Citrasiwi, G., Hafiar, H., \& Sjoraida, D. F. (2017). Pembentukan Sikap Masyarakat Terhadap Kesehatan Diri Melalui Kampanye 10 Perilaku Hidup Bersih Dan Sehat. Jurnal Visi Komunikasi.

Emma Mohamad, Nur Afiqah Mohd Haniff, Sabariah Mohamed Salleh, A. L. A. \& H. H. (2015). Media Dan Literasi Kesihatan: Pemilihan Susu Tumbesaran KanakKanak Dalam Kalangan Ibu. Jurnal Komunikasi, Malaysian Journal of Communication.

Fajriani, H., Aliyudin, M., \& Ridwan, A. (2020). Respon Mubaligh Banten terhadap Materi Dakwah Ustad Evie Effendi tentang Nabi Sesat. Tabligh: Jurnal Komunikasi Dan Penyiaran Islam. https://doi.org/10.15575/tabligh.v5i3.193 6

Grier, S., \& Bryant, C. A. (2005). Social Marketing in Public Health. Annual Review of Public Health. https://doi.org/10.1146/annurev.publhealt h.26.021304.144610

Handayani, R., Novaryatiin, S., \& Ardhany, S. D. (2016). Sosialisasi Perilaku Hidup Bersih dan Sehat pada Anak-Anak Tingkat Sekolah Dasar di Desa Tabore Kecamatan Mentangai Kalimantan Tengah. Jurnal Surya Medika. https://doi.org/10.33084/jsm.v2i1.363

Hardianto, A. W. (2019). Analisis StimulusOrganism-Response Model Pada "Dove 
Campaign for Real Beauty” $2004-2017$. Jurnal Transaksi.

Ishikawa, H., \& Kiuchi, T. (2010). Health literacy and health communication. In BioPsychoSocial Medicine. https://doi.org/10.1186/1751-0759-4-18

Ismayani, N. (2019). Kesiapsiagaan terhadapi Bencana Gempa dan Tsunami (Kampung Koto Nagari Sungai Pisang Kabupaten Pesisir Selatan). Jurnal Pengabdian Kepada Masyarakat Dewantara.

Karim, H. A. (2020). Health literacy among rural communities: Issues of accessibility to information and media literacy. Jurnal Komunikasi: Malaysian Journal of Communication. https://doi.org/10.17576/JKMJC-20203601-14

Karsidi, R. (2001). Paradigma Baru Penyuluhan Pembangunan dalam Pemberdayaan Masyarakat. Jurnal Mediator.

Klingemann, H.-D. A. R. (2002). Public Information Campaigns \& Opinion Research. A Handbook for the Student \& Practioner. Vasa.

Klingemann, H.-D., \& Römmele, A. (2011). Public Information Campaigns and Opinion Research. In Public Information Campaigns and Opinion Research. https://doi.org/10.4135/9780857024534

Klingemann, H.-D., Römmele, A., Voltmer, K., \& Römmele, A. (2011). Information and Communication Campaigns: Linking Theory to Practice. In Public Information Campaigns and Opinion Research. https://doi.org/10.4135/9780857024534.d 7

Krishnan, M., \& A. Rahim, S. (2015). Hubungkait Komunikasi Kesihatan dengan Kesan Hirarki Isu Kesihatan terhadap Perubahan Amalan Gaya Hidup Sihat (The Relationship of Health Communication with the Hierarchy of Effect in Health Issues Towards Healthy Life Style). Jurnal Komunikasi, Malaysian Journal of Communication. https://doi.org/10.17576/jkmjc-20143001-08

L.Gibson, J., Ivancevich, J. M., Jr., J. H. D., \& Konopaske, R. (2017). Organizations Behavior, Structure, Processes, Fourteenth Edition. In BMC Public Health.
Malik, F., Bafadal, M., Wahyuni, \& Sahidin. (2020). Edukasi Perilaku Hidup Bersih dan Sehat (PHBS), Gerakan Menggunakan Masker (GEMAS), serta penggunaan antiseptik dan desinfektan di Desa La Nipa Nipa, Kecamatan Katoi, Kolaka Utara, Provinsi Sulawesi Tenggara. Jurnal Pengabdian Masyarakat.

Mardikanto, T. (2001). Sistem Penyuluhan Pertanian. Ekstensia. https://doi.org/10.2174/13892031280358 2960

McQuail, D. (2016). Mass Communication. In The International Encyclopedia of Political Communication. https://doi.org/10.1002/9781118541555. wbiepc 155

Mohamad, E., \& Azlan, A. A. (2020). COVID19 and communication planning for health emergencies. In Jurnal Komunikasi: Malaysian Journal of Communication.

Mulyana, D. (2007). Ilmu komunikasi. In Bandung Rosdakarya.

Munawaroh, D., Suherdiana, D., \& Nase, N. (2020). Respon Jamaah Terhadap Dakwah Terhadap Dakwah Melalui TQN (Tarekat Qodiriyah Naqsabandiyah) (Penelitian di Pondok pesantren Ibnu Ajhari Bekasi). Tabligh: Jurnal Komunikasi Dan Penyiaran Islam. https://doi.org/10.15575/tabligh.v5i1.177 9

Nicely Aken, S. (2008). Health Communication: From Theory to Practice. Journal of the Medical Library Association: JMLA. https://doi.org/10.3163/15365050.96.1.72

Peng, Y., Pei, C., Zheng, Y., Wang, J., \& Zhang, K. (2020). Knowledge , Attitude and Practice Associated with COVID-19 among University Students: a CrossSectional Survey in China. Research Square.

Rice, R. E., \& Atkin, C. K. (2017). Public Communication Campaigns. In Public Communication Campaigns. https://doi.org/10.4135/9781544308449

Rimal, R. N., \& Lapinski, M. K. (2009). Why health communication is important in public health. In Bulletin of the World Health

Organization. 
https://doi.org/10.2471/BLT.08.056713

Robandi, D., Ritonga, I., Junaidi, T. P., Rusdinal, \& Gistituati, N. (2020). An Analysis of Education Policy in the Pandemic COVID-19. Seminar Nasional: Jambore Konseling 3.

Sakinah, N., Sumijaty, S., \& Rahman, E. T. (2020). Respon Komunitas Pemuda Faiths Terhadap Kajian Khitobah Berbasis Materi Tauhid. Tabligh: Jurnal Komunikasi dan Penyiaran Islam. https://doi.org/10.15575/tabligh.v4i1.660

Sampurno, M. B. T., Kusumandyoko, T. C., \& Islam, M. A. (2020). Budaya Media Sosial, Edukasi Masyarakat, dan Pandemi COVID-19. SALAM: Jurnal Sosial Dan Budaya Syar-I. https://doi.org/10.15408/sjsbs.v7i5.15210

Saputra, R. (2016). Efek game online terhadap kreatifitas berpikir anak di Kelurahan Kadia Kecamatan Kadia Kota Kendari. Journal Ilmu Komunikasi UHO: Jurnal Penelitian Kajian Ilmu Komunikasi Dan Informasi.

Setyawan, D. (2001). Penyuluhan. Journal of Chemical Information and Modeling. https://doi.org/10.1017/CBO9781107415 324.004

Snyder, L. B. (2007). Health Communication Campaigns and Their Impact on Behavior. Journal of Nutrition Education and Behavior. https://doi.org/10.1016/j.jneb.2006.09.00 4

Thomas, R. K. (2006). Health communication. In Health Communication. https://doi.org/10.1007/0-387-26116-8

Tucker, S., \& United Nations Development Programme. (2014). Social Innovation for Public Service Excellence. Global Cantre for Public Execellence.

Wahyudin, \& Uud. (2016). Membangun Model Kampanye Komunikasi Kesehatan PHBS di Jawa Barat. Jurnal Ilmu Politik Dan Komunikasi.

Wang, C., Pan, R., Wan, X., Tan, Y., Xu, L., McIntyre, R. S., Choo, F. N., Tran, B., Ho, R., Sharma, V. K., \& Ho, C. (2020). A longitudinal study on the mental health of general population during the COVID-19 epidemic in China. Brain, Behavior, and Immunity. https://doi.org/10.1016/j.bbi.2020.04.028

Yanuardianto, E. (2019). Teori Kognitif Sosial Albert Bandura (Studi Kritis Dalam Menjawab Problem Pembelajaran di Mi). Auladuna: Jurnal Prodi Pendidikan Guru Madrasah Ibtidaiyah, 1(2), 94-111. https://doi.org/10.36835/au.v1i2.235

Zukmadini, A. Y., Karyadi, B., \& Kasrina, K. (2020). Edukasi Perilaku Hidup Bersih dan Sehat (PHBS) dalam Pencegahan COVID-19 Kepada Anak-Anak di Panti Asuhan. Jurnal Pengabdian Magister Pendidikan IPA, 3(1). https://doi.org/10.29303/jpmpi.v3i1.440 
